(c) Group of authors, 2017

UDC 616.329-089.86-053.2/.5

DOI - https://doi.org/10.14300/mnnc.2017.12085

ISSN - 2073-8137

\title{
OUR EXPERIENCE OF SECONDARY MULTISTAGE TREATMENT FOR COMPLEX LONG GAP ESOPHAGEAL ATRESIA
}

Sterlin A. ', Ötzmann von Sochaczewski Ch. ', Fotache G. ${ }^{2}$, Engel V. ${ }^{1}$, Gödeke J. ', Muensterer O. ${ }^{1}$

1 Johannes Gutenberg Universität, Mainz, Germany

2 Institutul National de Pneumoftiziologie «Marius Nasta», Bukarest, Romania

\section{ОПЫТ ВТОРИЧНОГО ПОЭТАПНОГО АЕЧЕНИЯ АЕТЕЙ С АТРЕЗИЕЙ ПИЩЕВОАА С ОСАОЖНЕНИЯМИ ПОСАЕ АНАСТОМОЗА ПИЩЕВОАА}

\author{
А. Стерлин ', К. Эцман фон Сохачевски ', Г. Фотаче ${ }^{2}$, В. Энгель ', \\ Я. Гёлеке ${ }^{1}$, О. Мюнстерер ${ }^{1}$ \\ 1 МеАицинский университет, Майнц, Германия \\ 2 Национальный институт пульмофттзиатрии «Мариус Наста॥, Бухарест, Румыния
}

Currently, there is no uniform consensus in treatment of complex long-gap esophageal atresia (CLGEA). In our department, we perform an anastomosis of the native esophagus after patient-adapted elongation therapy by esophageal traction. This study describes results, challenges, and complications of our approach.

Keywords: long-gap esophageal atresia, multistage treatment, Foker procedure, Kimura procedure

На сегодняшний день отсутствует единый подход в лечении пациентов с большим диастазом при атрезии пищевода. В работе представлен опыт наложения анастомоза после поэтапного удлинения пищевода, результаты и сложности, с которыми мы столкнулись, используя методику поэтапной элонгации пищевода.

Ключевые слова: атрезия пищевода с большим диастазом, поэтапное удлинение пищевода, операция Фокера, операция Кимура

T here is no uniform consensus in treatment of complex long-gap esophageal atresia (CLGEA) $[3,4,6,7,9]$. The controversy is mostly based on severity and variety of complications of the anastomosis $[5,8,10,11]$. In our department, we perform an anastomosis of the native esophagus after patient-adapted elongation therapy avoiding gastric pull-up and colonic interposition.

The aim of study was to investigation of challenges and results of our approach lengthening procedure in children with long-gap esophageal atresia.

Material and Methods. Five children with CLGEA ( $\geq 5$ vertebral bodies gap) were referred to our department in 2016. All patients had been operated on previously at out- side facilities. All children were admitted to our department with esophagostomy and gastrostomy after having anastomotic insufficiency and/or esophageal- (in two cases) or colonic interponate necrosis (in one case). As one of our major goals is to perform an anastomosis of the native esophagus, we used a Foker-technique [1, 2] (Fig. 1) using traction sutures to lengthen the esophageal pouches within days and multistaged extrathoracic esophageal elongation described by Kimura [2] (Fig. 2), to solve the long gap problem and make a primary repair possible.

Outcome variables included number and type of interventions, stenosis and anastomotic leak rates, number of dilatations, time to oral feeding, postanastomotic weight gain, and other complications.

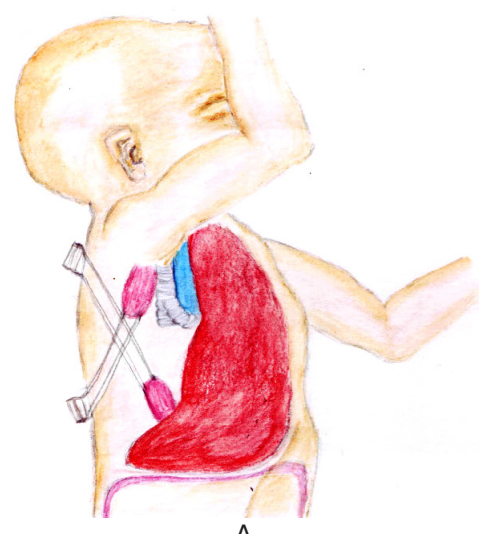

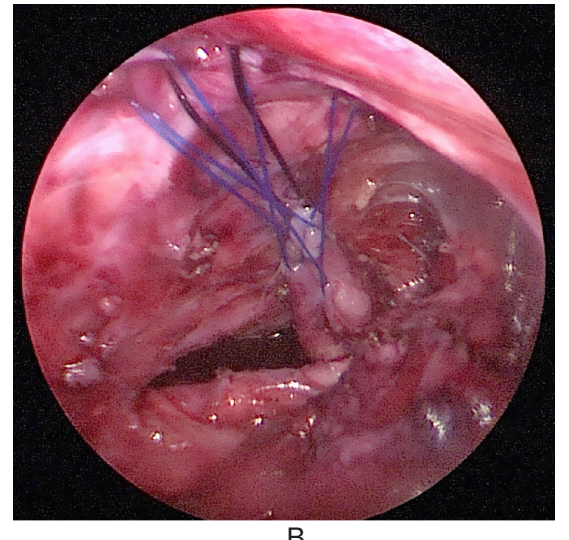

B

Fig. 1. The Foker lengthening procedure: A - principle of Foker lengthening procedure; $\mathrm{B}$ - intraoperative view by internal Foker lengthening procedure 


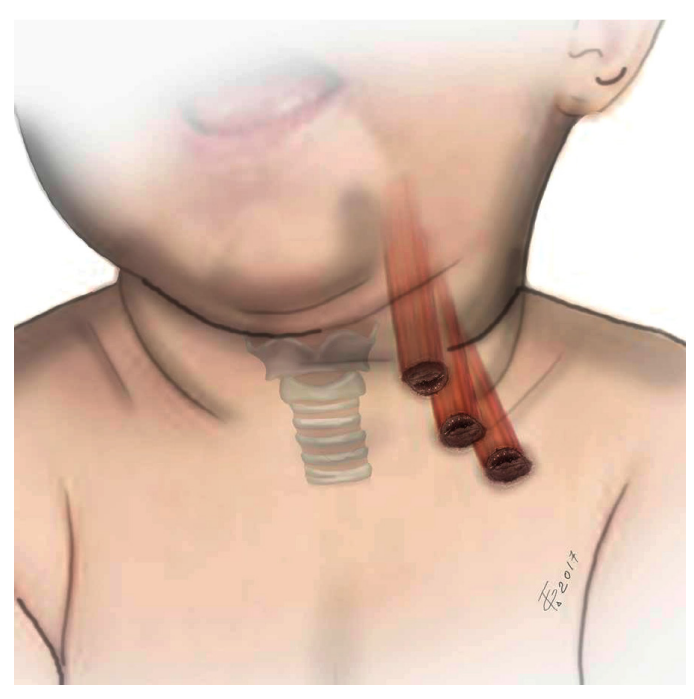

Fig. 2. Principle of Kimura lengthening procedure

Results and Discussion. All 5 children survived with their native, patent esophagus. Each child underwent a maximum of 3 Kimura procedures, which correlates with earlier published mean operation numbers [3]. After the desired elongation of the upper pouch has been achieved, this success was «supported» with at least 1 Foker operation (Fig. 3). Average time between interventions was $15 \pm 3$ days. After the anastomosis, the mean time to oral feeds was $10 \pm 3$ days. Only one child developed anastomotic leakage.

Anastomotic stricture is the most common complication following operative repair [5]. Balloon dilatation was necessary in 4 cases; each of these patients was dilated 3-5 times (Fig. 4). Postanastomotic weight gain at 4-month mean follow-up was an average $19 \pm 4 \mathrm{~g} /$ day. Two patients had recurrent laryngeal nerve palsy, of which one has recovered in follow-up interval.

Two children developed gastroesophageal reflux in 2-month follow-up after anastomosis. Nevertheless the prevalence of gastroesophageal reflux after replacement of the esophagus is much higher $[6,7,8,9,10]$ as well as anastomotic leak, stricture and respiratory problems [11].

\section{References}

1. Foker J. E., Linden B. C., Boyle Jr. E. M. [et al.] Development of atrueprimary repair for the full spectrum of esophageal atresia. Ann. Surg. 1997;226:533-43.

2. Till H., Muensterer O. J., Rolle U., Foker J. Staged esophageal lengthening with internal and subsequent external traction sutures leads to primary repair of an ultralong gap esophageal atresia with upper pouch tracheoesophagel fistula. J. Pediatr. Surg. 2008;43:E33E35.

3. Kimura K., Soper R. T. [et al.] Multistaged extrathoracic esophageal elongation for long gap esophageal atresia. J. Pediatr. Surg. 1994;29(4):566-568

4. Kimura K., Nishijima E., Tsugawa C., Collins D. L., Lazar E. L. [et al.] Multistaged extrathoracic esophageal elongation procedure for long gap esophageal atresia: Experience with 12 patients. J. Pediatr. Surg. 2001:36(11):1725-1727.

5. Tambucci R., Angelino G., De Angelis P., Torroni F., Caldaro T. [et al.] Anastomotic Strictures after Eso phageal Atresia Repair: Incidence, Investigations, and Management, Including Treatment of Refractory and Recurrent Strictures. Front. Pediatr. 2017;29(5):120. doi: 10.3389/fped.2017.00120

6. Zeng Z., Liu F., Ma J., Fang Y., Zhang H. Outcomes of primary gastric transposition for long-gap esophageal atresiain neonates. Medicine(Baltimore). 2017;96(6):e7366. doi: 10.1097/MD.0000000000007366

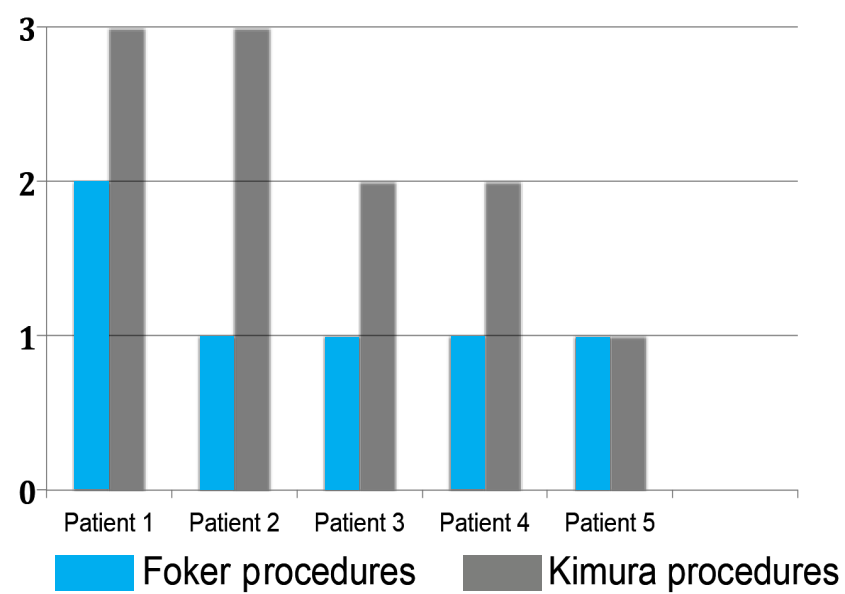

Fig. 3. Number of Kimura and Foker operations in each case

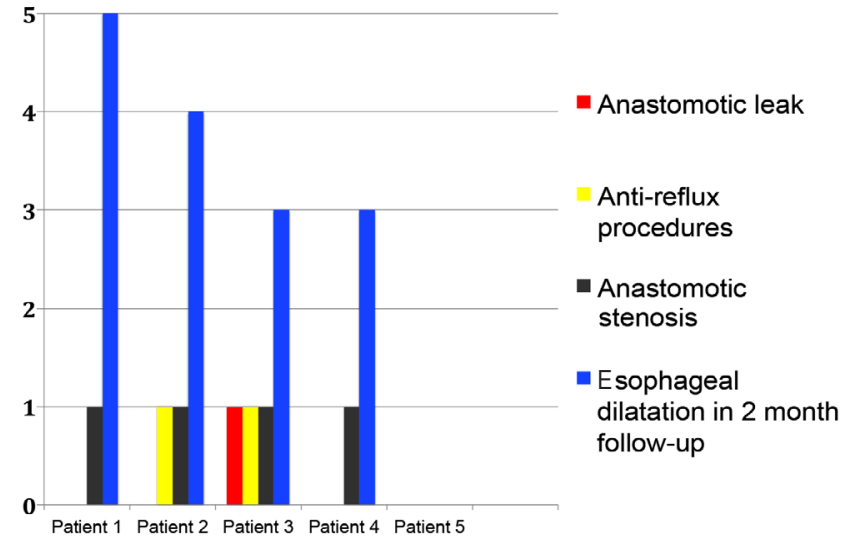

Fig. 4. Number and type of complications

Conclusions. Multistage esophageal elongation using combined Kimura and Foker techniques is a challenging undertaking that requires a series of surgical interventions. However, anastomosis of the native esophagus can be achieved. Pros and cons must therefore be carefully weighed.

7. Rintala R. J. Fundoplication in Patients with Esophageal Atresia: Patient Selection, Indications, and Outcomes. Front. Pediatr. 2017;15(5):109. doi: 10.3389/ fped.2017.00109

8. Garritano S., Irino T., Scandavini C. M., Tsekrekos A., Lundell L. [et al.] Long-term functional outcomes after replacement of the esophagus in pediatric patients: A systematic literature review. J. Pediatr. Surg. 2017 Jun 8. pii: S0022-3468(17)30353-6. doi: 10.1016/j. jpedsurg.2017.05.034

9. Gupta D. K. Sharma S., Arora M. K., Agarwal G., Gupta $M$. [et al.] Esophageal replacement in the neonatal period in infants with esophageal atresia and tracheoesophageal fistula. J. Pediatr. Surg. 2007;42(9):14711477.

10. Friedmacher F., Kroneis B., Huber-Zeyringer A., Schober P., Till H. [et al.] Postoperative Complications and Functional Outcome after Esophageal Atresia Repair: Results from Longitudinal Single-Center Follow-Up. J. Gastrointest. Surg. 2017;21(6):927-935. doi: 10.1007/s11605-017-3423-0

11. Liu J., Yang Y., Zheng C., Dong R., Zheng S. Surgical outcomes of different approaches to esophageal replacement in long-gap esophageal atresia: A systematic review. Medicine (Baltimore). 2017;96(21):e6942. doi: 10.1097/MD.0000000000006942 
About authors:

Sterlin Alexander, MD, Fellow of Department of Pediatric Surgery; tel.: +496131170; e-mail: Alexander.Sterlin@unimedizin-mainz.de

Ötzmann von Sochaczewski Christina, MD, PhD, Fellow of Department of Pediatric Surgery;

tel.: +496131170; e-mail: Christina.Oetzmann@unimedizin-mainz.de

Fotache Georgiana, MD, Fellow of Department of Thoracic Surgery; http://linkedin.com/in/georgiana-fotache-b4b16b35

Veronika Engel, MD, PhD, Department of Pediatric Surgery; tel.: +496131170; e-mail: Veronika.Engel@unimedizin-mainz.de

Gödecke Jan, MD, PhD, Department of Pediatric Surgery; tel.: +496131170; e-mail: Jan.Goedecke@unimedizin-mainz.de

Muensterer Oliver, MD, PhD, FAAP, FACS, FEBPS, Univ.-Professor, Department of Pediatric Surgery;

tel.: +49613117111; e-mail: Oliver.Muensterer@unimedizin-mainz.de

(c) Group of authors, 2017

UDC 616.71-018.44-002.2-089.844

DOI - https://doi.org/10.14300/mnnc.2017.12098

ISSN - 2073-8137

\title{
APPLICATION OF POROUS TITANIUM NICKELIDE FOR TREATMENT OF PATIENTS WITH CHRONIC OSTEOMYELITIS
}

Shtofin A. S., Shegolev M. B., Trushin P. V., Golovnev V. A., Golovnev A. V., Shtofin S. G.

Novosibirsk State Medical University, Russian Federation

\section{ПРИМЕНЕНИЕ ПОРИСТОГО НИКЕАИАА ТИТАНА ААЯ АЕЧЕНИЯ БОАЬНЫХ ХРОНИЧЕСКИМ ОСТЕОМИЕАИТОМ}

\author{
А. С. Штофин, М. Б. Щеголев, П. В. Трушин, В. А. Головнев, А. В. Головнев, С. Г. Штофин
}

Новосибирский госуАарственный меАицинский университет, Российская ФеАерация

The research covered patients with chronic osteomyelitis. 55 patients underwent an original operation of single stage sequestrectomy and grafting the residual bone cavity with fine-grain titanium nickelide. There was demonstrated clinico-roentgenologic efficiency of this treatment method in early rehabilitation period and further follow up. Clinical effects were characterized by the absence of relapses of chronic osteomyelitis in $94.6 \%$ of patients during the followup period. The inductive influence of titanium nickelide in the formation of trabecular bone tissue was experimentally based on 20 animals (dogs). Thus, our work confirms that the use sequestrectomy with the following grafting with the granules of titanium nickelide gives more positive results than the traditional method of treatment of the chronic osteomyelitis.

Keywords: chronic osteomyelitis, titanium nickelide, bone grafting, surgical treatment

В исследование включены 83 пациента с хроническим остеомиелитом (ХO), из них 55 больным была проведена оригинальная операция одномоментной секвестрэктомии и пластики остаточной костной полости мелкогранулированным никелидом титана. Продемонстрирована клинико-рентгенологическая эффективность данного метода лечения в раннем реабилитационном и в отдаленном периоде наблюдения. Клинические эффекты характеризовались отсутствием рецидивов XО у 94,6 \% больных в течение всего срока наблюдения. Экспериментально на 20 животных (собаках) было установлено индуцирующее действие никелида титана в процессе формирования зрелой костной ткани. Полученные результаты свидетельствуют о том, что применение метода лечения XO путем секвестрэктомии с последующей пластикой гранулами никелида титана дает большее количество положительных результатов в сравнении с традиционным методом лечения.

Ключевые слова: хронический остеомиелит, никелид титана, пластика, хирургическое лечение

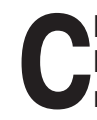
hronic osteomyelitis is pathology of the bone system, accompanied not only by local manifestations, but changes in the whole body. Taking into account that the average age of the patients with chronic osteomyelitis (CO) is $30-40$ years old. In the whole structure of diseases of locomotor organs, CO constitutes 3-6.5\%, occupying the first place among the complications after the operational treatment of closed fractures [1, 2]. In recent years a tendency is noticed towards the increase in the frequency of the disease. Among other purulent-septic diseases, $\mathrm{CO}$ is characterized by long-lasting and progressive development, resistance to treatment, predisposition to relapses [3]. Besides, during the last two decades, the number of patients with postoperational osteomyelitis increased dramatically - up to $34 \%$ among the observed patients [4]. At present, there are no unique criteria in the assessment of efficiency of methods of treating $\mathrm{CO}$, in particular, the elimination of osteomyelitis bone cavities. The opinions of surgeons $[2,5]$ coincide in the question of radical surgical manipulation with osteomyelitis 